\title{
Analysis of The Morphological Characteristics of Bush Frog Philautus spp. Gistel, 1848 (Anura: Rhacophoridae) from Mount Ungaran
}

\author{
Margareta Rahayuningsih $^{1}$, Winda Rahmawati ${ }^{1}$, Amir Hamidy $^{2}$ \\ ${ }^{1}$ Department of Biology, Faculty of Mathematics and Natural Sciences, Universitas Negeri Semarang, Indonesia \\ ${ }^{2}$ Research Center for Herpetology, Indonesian Institute of Sciences (LIPI), Indonesia \\ *Corresponding Author: etak_sigid@mail.unnes.ac.id
}

Submitted: 2021-05-23. Revised: 2021-07-21. Accepted: 2021-08-13

\begin{abstract}
Traditionally, the genus Philautus Gistel, 1848 contains small Rhacoporid frogs that lack vomerine teeth and a direct development tadpole stage. In Java, this genus consists of 3 species, including Philautus aurifasciatus, Philautus jacobsoni, and Philautus pallidipes. It is known that Philautus aurifasciatus and Philautus jacobsoni are sympatric species from Mount Ungaran and are morphologically difficult to distinguish. Therefore, information is needed through the phenetic characters of each population in the area to identify differences in their morphology. This study aimed to analyze the morphological characteristics of Bush Frog Philautus spp. on Mount Ungaran in terms of meristic character through a direct field survey and comparison methods. Furthermore, it was conducted by observing 32 specimens of Philautus spp. from Mount Ungaran and compared with the Philautus aurifasciatus from Mount Gede Pangrango with 18 meristic characters. The results showed that Philautus spp. is similar to Philautus aurifasciatus in terms of their meristic characters. The results of the meristic analysis showed that Philautus spp. has a variety of dorsal colors from brown, purple, green, and gray with two types of patterns including patterned groups (resembling letters $\mathrm{H}, \mathrm{X}$, and V) and abstract. Furthermore, the throat, stomach, and lower thighs are granular with three snout shapes (protruding, round, and sloping). It has a loreal oblique tympanum and canthus rostralis. The forelimbs are not webbed while the hindlimbs are half webbed, and the inner metatarsal is an elongated oval in shape. Meristic analysis provides a basis for strengthening the taxonomic status of Philautus spp on Mount Ungaran, as well as information the distribution in Mount Ungaran.
\end{abstract}

Key words: bush frog; morphology; Mount Ungaran; Philautus; taxonomy

How to Cite: Rahayuningsih, M., Rahmawati, W., \& Hamidy, A. (2021). Analysis of The Morphological Characteristics of Bush Frog Philautus spp. Gistel, 1848 (Anura: Rhacophoridae) from Mount Ungaran. Biosaintifika: Journal of Biology \& Biology Education, 13(2), 250-257.

DOI: http://dx.doi.org/10.15294/biosaintifika.v13i2.31298

\section{INTRODUCTION}

Bush Frog Philautus Gistel, 1848 is a genus of frogs from the Rhacophoridae family. It has a small body of about $2-3 \mathrm{~cm}$, the pupil is horizontal, and it has no vomerine teeth with a distinct or hidden tympanum (Bossuyt \& Dubois, 2001). Molecular taxonomic evaluation on the generic level among Rhacophorid frogs, placed Philautus with species of $P$. aurifasciatus as a valid genus (Biju et al., 2020). The distribution of Philautus in Central India and then continue through Myanmar, Thailand, the Philippines, and also the Greater Sunda Islands (Sumatra, Java, and Kalimantan), it consists of 55 species (Frost, 2020). In the Greater Sunda region, they are very similar to each other morphologically (Malkmus et al., 2002; Dehling, et al. 2016). Based on these similarities, Dring (1987) grouped Philautus from Borneo into four major groups, namely: 1) the Aurifasciatus 2) the Hosii, 3) the Tectus, and 4) the Vermiculatus.

Aurifasciatus groups distributed in Java include Philautus aurifasciatus (Schlegel, 1837), Philautus jacobsoni (Van Kampen, 1912), and Philautus pallidipes (Barbour, 1908) (Kusrini et al., 2017; Wostl et al., 2017; Frost, 2020). P. aurifasciatus (Schlegel, 1837) is distributed in Java and Thailand (Frost, 2020) and was first discovered in Mount Gede Pangrango, West Java (Kuhl \& Hasselt, 1822; Van Kampen, 1912). Meanwhile, Philautus jacobsoni is known as an endemic species found in Mount Ungaran, Central Java (Van Kampen, 1912; Iskandar, 1998; Frost, 2020). However, since its first discovery, there is no record of its rediscovery (Iskandar, 1998). Philautus aurifasciatus and $P$. jacobsoni are sympatric species on Mount Ungaran and they are very similar in morphology (Iskandar, 1998).

Furthermore, a study conducted by Iskandar and Mumpuni (2004) showed that Philautus aurifasciatus was found in Central Java. A study conducted on Mount Ungaran with LIPI (Indonesian Institute of Sciences) in 2018 showed that there was a type of frog identified as Philautus aurifasciatus based on its morphological characteristics. However, the classification of the Philautus species was not based on taxonomy and diversity studies. Therefore, there is a need for further study the phenetic characters to describe the Philautus species, especially those found 
in Mount Ungaran area to identify differences in their morphology.

Mount Ungaran is one of the last remaining forest and established of the Alliance Zero Extinction Area (AZE) (Rahayuningsih et al., 2017b) that serve as a home to Philautus jacobsoni. This endemic species has not been rediscovered in more than 100 years, and it is very similar to Philautus aurifasciatus. This study aimed to compare the morphological characteristics of Philautus spp. obtained from Mount Ungaran with MZB (Museum Zoologicum Bogoriense) LIPI collection specimens from Mount Gede Pangrango as a topotype based on meristic characters. Merisric analysis provides a basis for strengthening the taxonomic status of Philautus spp on Mount Ungaran, as well as information the distribution in Mount Ungaran.

\section{METHODS}

\section{Study area}

This field study was conducted from May to December 2019. The field study was conducted in the Mount Ungaran area with 6 sampling stations including Curug Lawe Benowo Kalisidi, Banyuwindu Village, Gentong Hill, Promasan Hill, Gajahmungkur Village, and Gempol Village (Figure 1). Morphological data was collected at the Animal Taxonomy Laboratory of the Department of Biology, Universitas Negeri Semarang and data analysis was carried out at the Herpetofauna Biosystematics Laboratory, Center for Biological Research, LIPI from December 2019 to February 2020.

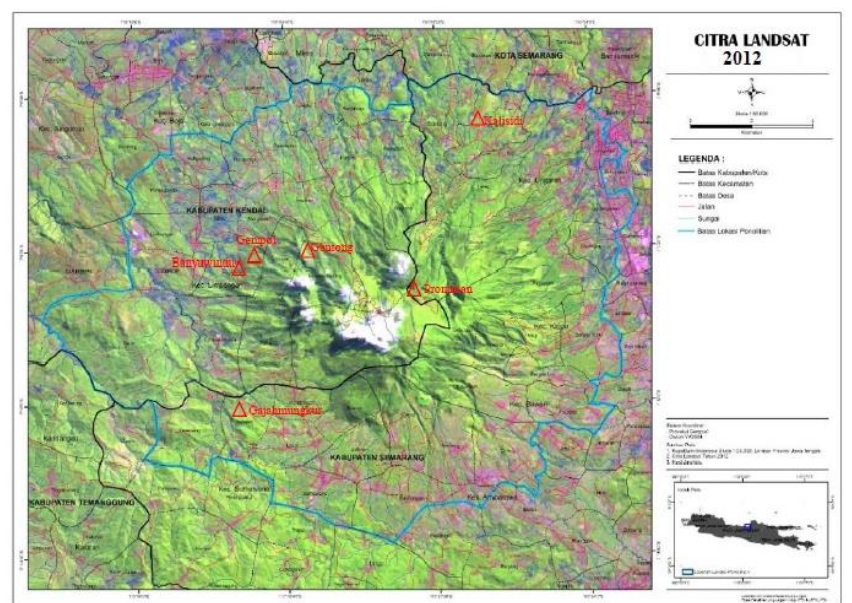

Figure 1. Mount Ungaran (Central Java, Indonesia) and sample collection stations in the field (triangle sign) (Rahayuningsih et al., 2017a)

\section{Procedures \\ Data of population}

The population data was collected by exploration on all habitat of the Philautus on Mount Ungaran. The search for specimens was performed by walking on predetermined sampling path based on field surveys that had been carried out previously. Sampling was carried out during active time of the herpetofauna, which were in the night (19.00-22.00 WIB). Philautus samples taken were adults between $15-25 \mathrm{~mm}$ for males and 25-33 mm for females (Iskandar, 1998). The specimens obtained were photographed in the field using a digital camera as a photo of fresh specimens. Then the specimens were captured and each given a field number. The results of the specimen collection are presented in the table provided. The specimens obtained were then preserved in a jar containing $70 \%$ alcohol for preservation.

\section{Data for morphological analysis}

Meristic character data collection was done by directly observing the specific characters to be observed. Observations of meristic characters were carried out on the specimens from Mount Ungaran (28 males; 4 females) and Mount Gede Pangrango (25 males; 7 females) using 17 meristic characters. The meristic characters used are based on the literature studies from the original descriptions (Table 1).

\section{Data analysis}

Population descriptions was made based on the population data that was collected in the field by analyzing the entire number of individuals found in all sampling stations. The analysis was carried out to examine the differences and similarities between the Philautus spp. from Mount Ungaran and Philautus aurifasciatus from Mount Gede Pangrango.

Data obtained from meristic observations were entered into Microsoft Excel 2016 format and separated between male and female individuals. Meristic observation analysis was carried out descriptively with the help of the identification book titled Amphibians and Reptiles of Mount Kinabalu (North Borneo).

\section{RESULTS AND DISCUSSION}

\section{Meristic characters Philautus spp. Mount Ungaran}

Meristic observations of 32 Philautus spp. (28 males and 4 females) showed variations in meristic characters, i.e. in body complexion and snout shape. Philautus spp. from mount Ungaran has a total SVL (Snout Venth-Length) ranging from $16.83-23.26 \mathrm{~mm}$ in male specimens and $24.91-27.98 \mathrm{~mm}$ in females. Furthermore, this species does not have vomer teeth and papillae on the tongue. The head is large with a short and sharp snout with three types of shape, i.e. 1) round, 2) protruding, and 3) sloping. It is also known to have a variety of pattern style types including: letters of $\mathrm{H}, \mathrm{X}$, and $\mathrm{V}$, and abstract pattern, or does not have a certain style. 


\section{H-Type}

H-type Philautus was the most often found on Mount Ungaran. It has a variety of patterns that resemble the letter $\mathrm{H}$ on the dorsal side and it is usually dark in color. This type of Philautus has a sloping and protruding snout with a distinct and concave canthus rostralis, sloped and slightly concave loreal area, and distinct tympanum hidden by the skin. There is also a supratympanic fold that protrudes from the back of the eye to the shoulder (Figure 2).
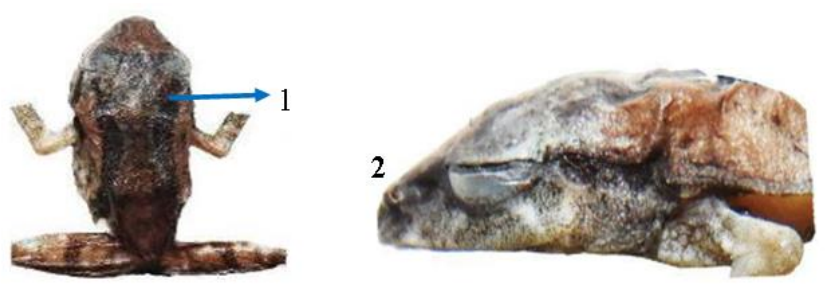

Figure 2. H-type Philautus sp. (1) The dorsal pattern resembles the letter H; (2) Snout shape is sloping

H-type Philautus has smooth dorsal skin and it is covered with nodules or small bumps all over the surface, especially on the occiput, eyes, and back. Granular skin texture is found on the throat, stomach, and under the thighs. Furthermore, the inner metatarsal tubercle is in the shape of an elongated oval, and the forelimbs are webbed only at the base of the fingers, while the hindlimbs are half webbed in an arrangement of 1(1) 2(1/0.75) 3(2/0.75) 4(2/2) 5(1). This type of Philautus has three color variations of brown, purple, and green, accompanied by many dorsal blackish patches. Meanwhile, the ventral part has three color variations, i.e. gray, yellow, and brown (Figure 3).
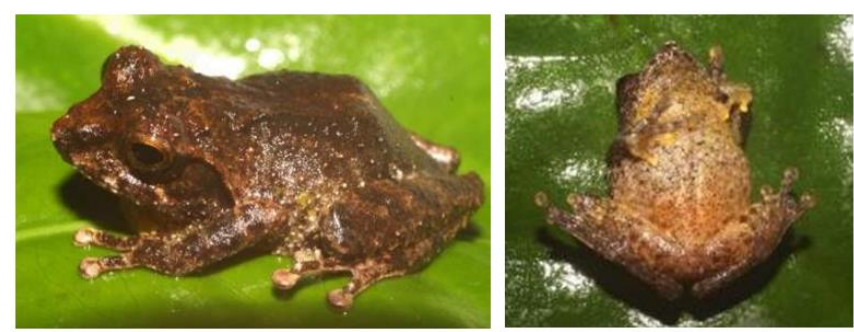

Figure 3. H-type Philautus sp. (colour variation)

\section{X-Type}

$\mathrm{X}$-type Philautus is also often found on Mount Ungaran with the patterns resembling the letter $\mathrm{X}$ on the dorsal side, usually dark in color. It has protruding and round snout types, with a distinct and concave canthus rostralis, a sloped loreal area, and slightly concave tympanum that hidden by the skin. Furthermore, this species has a fold of skin protruding from the back of the eye to the shoulder (Figure 4).
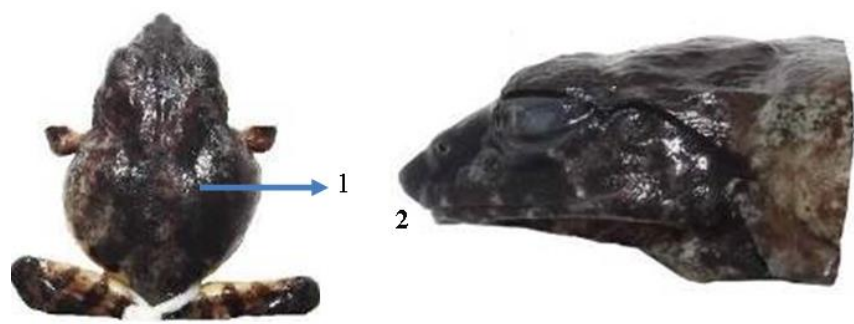

Figure 4. X-type Philautus sp. (1) The dorsal pattern resembles the letter X; (2) Snout shape is protruding

Table 1. Analysis meristic characters (Schlegel, 1837; Van Kampen, 1912; Inger, 2005)

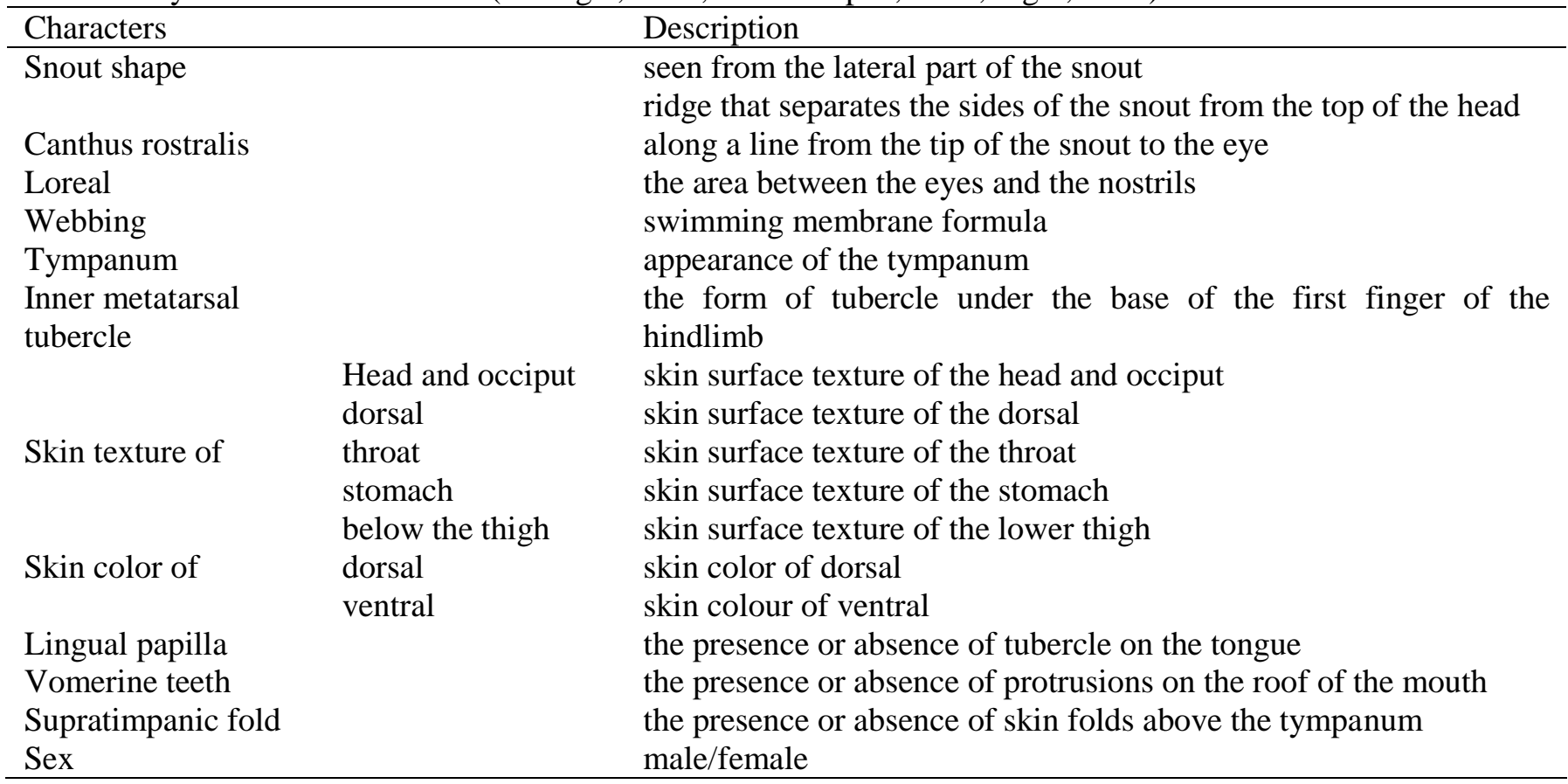


$\mathrm{X}$-type Philautus has smooth dorsal skin and it is covered with nodules or small bumps all over the surface, especially in the occiput, eyes, and back. Furthermore, granular skin texture is found on the throat, stomach, and under the thighs. The inner metatarsal tubercle is in the shape of an elongated oval, and the forelimbs are webbed only at the base of the fingers while the hindlimbs are half webbed in an arrangement of 1(1) 2(1/0.75) 3(2/0.75) 4(2/2) 5(1). This species has two color variations of brown to dark purple, sometimes accompanied by many dorsal blackish patches. Meanwhile, the ventral part has three color variations of gray, yellow, and brown (Figure 5).
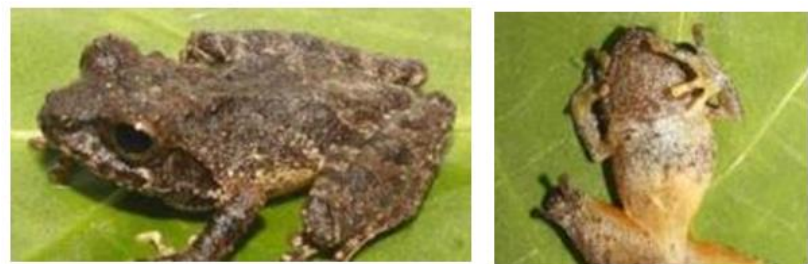

Figure 5. Life of X-type Philautus sp.

\section{V-Type}

V-type Philautus is rarely found on Mount Ungaran, and it has a variation of a V-like pattern. This pattern extends dorsally from the tip of the snout to the cloaca, and it is usually in a bright color like white or light brown. It has a distinct and concave caanthus rostralis, a sloped loreal area, and slightly concave tympanum that hidden by the skin. There is a fold of skin that protrudes from the back of the eye to the shoulder (Figure 6).
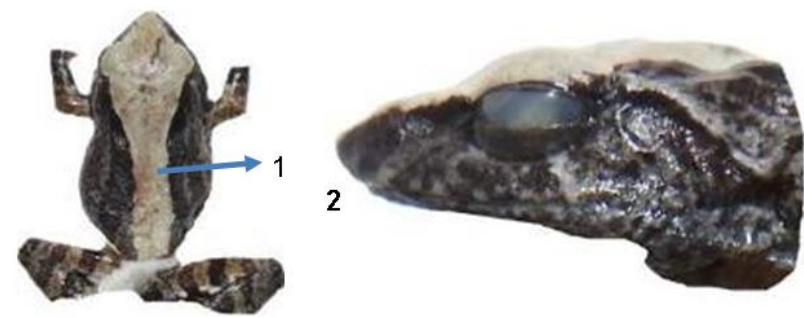

Figure 6. V-type Philautus sp. (1) The dorsal pattern resembles the letter V; (2) Snout shape is protruding

V-type Philautus has smooth dorsal skin covered with nodules or small bumps all over the surface, especially in the occiput, eyes, and back. Granular skin texture is also found on the throat, stomach, and under the thighs. The inner metatarsal tubercle is in the shape of an elongated oval, and the forelimbs are webbed only at the base of the fingers while the hindlimbs are half webbed in an arrangement of 1(1)
2(1/0.75) 3(2/0.75) 4(2/2) 5(1). This species has a dark brown with a slightly blackish patch on the dorsal side. Meanwhile, the ventral part has three color variations of gray, yellow, and brown (Figure $7)$.

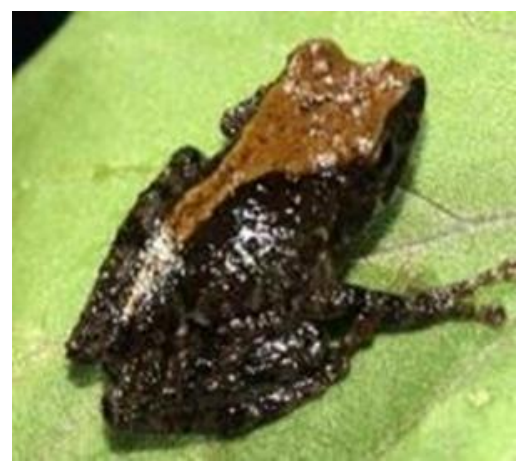

Figure 7. Life of V-type Philautus sp.

\section{Abstract-type}

Philautus that does not have a specific pattern or abstract is quite easy to find on Mount Ungaran. Such species have protruding and round snout types with a distinct and concave canthus rostralis, sloped loreal area, slightly concave tympanum that hidden by the skin. There is a fold of skin that protrudes from the back of the eye to the shoulder (Figure 8).
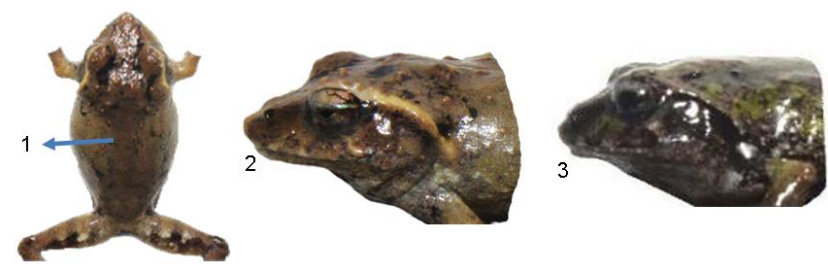

Figure 8. Philautus sp. Abstract type. (1) The dorsal pattern is not specific or abstract; (2) Snout shape is protruding; (3) Snout shape is round

The abstract type Philautus has smooth dorsal skin and it is covered with nodules or small bumps all over the surface, especially in the occiput, eye, and back. Granular skin texture is found on the throat, stomach, and under the thighs. The inner metatarsal tubercle is in the shape of an elongated oval, and the forelimbs are webbed only at the base of the fingers while the hindlimbs are half webbed in an arrangement of 1(1) 2(1/0.75) 3(2/0.75) 4(2/2) 5(1). Furthermore, this type of Philautus has three color variations of green, brown, and gray, which is accompanied by many dorsal blackish patches. The ventral part has three color variations of gray, yellow, and brown (Figure 9). 

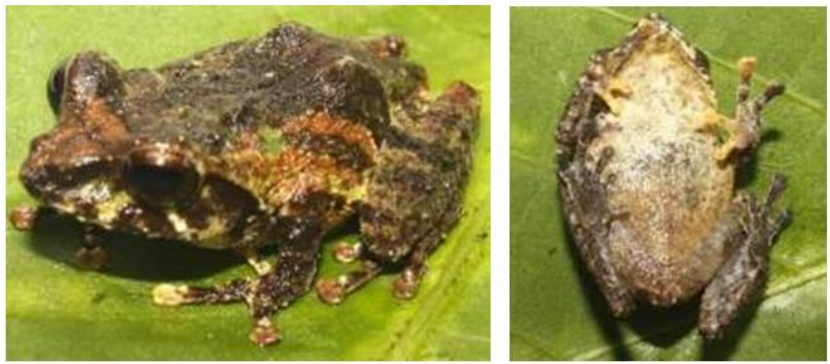

Figure 9. Life of Philautus sp. Abstract type

Philautus spp in mount Ungaran was known to have more than one type of snout, as well as the coloring pattern on the dorsal and ventral parts of its body. It has skin colors of purple, gray, green, to dark brown; sometimes accompanied by many dorsal blackish patches; while the ventral has a variety of colors such as gray, yellow, and brown. All members of the genus Philautus have varied morphological characteristics with a wide variety of colors and patterns, making it difficult to identify them (Iskandar, 1998; Malkmus et al., 2002; Matsui, 2009).

Several types of Philautus can change their patterns and colors at any time, and this is influenced by temperature and environmental conditions. Therefore, their body color will be difficult to be used as the main reference in identification. The results showed that temperature changes in several types of Philautus aurifasciatus affect the color contrast. For example, in the H-type Philautus, high temperature causes a change in green and dark purple to brown. Meanwhile, the black color will change back to normal when the species is placed in a cold room (Qurniawan, 2014).

The variety of Philautus aurifasciatus showed a high probability of random mating between individuals with different patterns (types) and colors (Qurniawan, 2014). Furthermore, random mating with different types and colors will increase the genetic wealth of the offspring. The types and color will be varied, however, another study should be conducted to prove this claim.

\section{Comparison of Philautus spp. from Mount Ungaran and Philautus aurifasciatus from Mount Gede Pangrango}

The meristic characters analysis result of the Mount Ungaran Philautus then compared with 32 samples (25 males; 7 females) of the Gede Pangrango Philautus specimen collection from Zoologicum Bogoriense Museum, Research Center for Biology, Indonesian Institute of Sciences. Furthermore, it showed that there was no variation in the meristic characters between individuals of the two mountain locations.

The meristic characters of the four types of Philautus sp. obtained from Mount Ungaran have been represented in Figure 2-9. Also, they were compared with the specimen of Philautus aurifasciatus obtained from Mount Gede Pangrango of MZB as a topotype. The comparison showed that meristic observations of 17 characters in the specimens of Philautus spp. and Philautus aurifasciatus showed some similarities (Table 2).

Table 2. Comparison of the meristic characters between Philautus from Mount Ungaran and Mount Gede Pangrango

\begin{tabular}{lcc}
\hline Characters & Philautus spp. & Philautus aurifasciatus \\
& Mount Ungaran & Mount Gede Pangrango \\
\hline
\end{tabular}

1. Tympanum distinct

2. Supratympanic fold

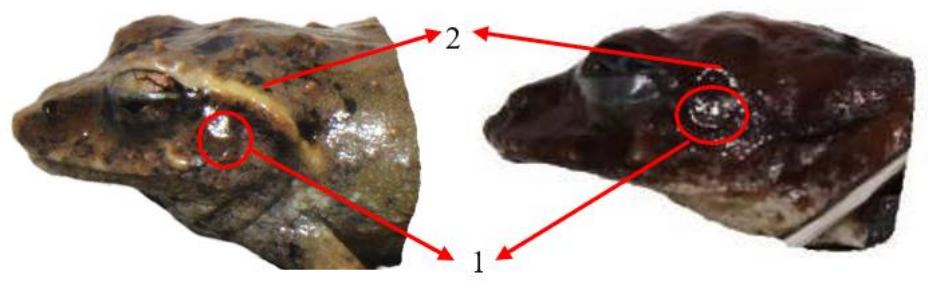

3. Sloped loreal

4.Canthus rostralis are distinct and rounded

5. Tubercle in the dorsal area including the occiput area and the upper eyelid

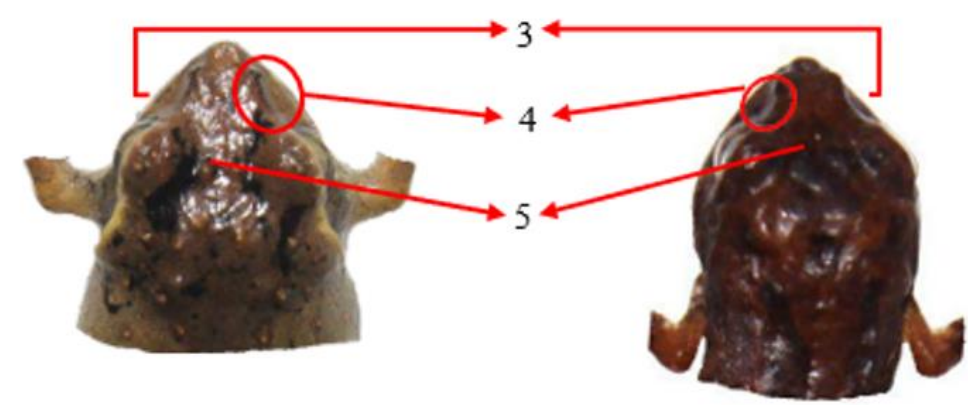




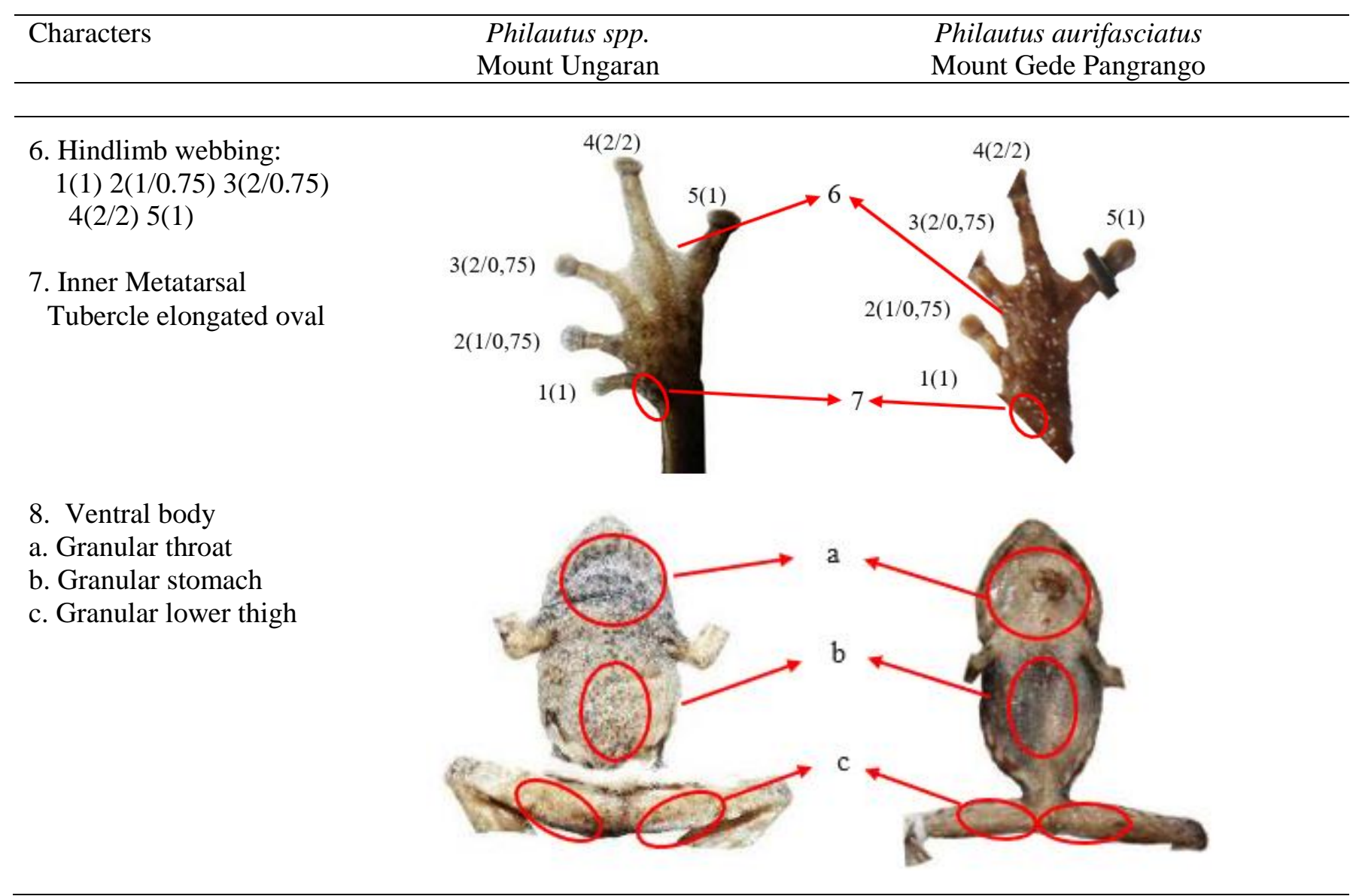

The arrangement of the toe webbing showed the consistency between individuals of each population. Furthermore, the forelimbs are only webbed at the base of the fingers, while the hindlimbs are half webbed with the webbing of 1(1) 2(1/0.75) $3(2 / 0.75)$ $4(2 / 2) 5(1)$ (Table 2 number 6$)$. On the $2^{\text {nd }}$ and $3^{\text {rd }}$ fingers, the outer side of the membrane position showed adhesion to the upper part of the $1^{\text {st }}$ subarticular tubercle, which is $0.75 \mathrm{~mm}$. The consistent pattern of swimming membrane arrangement is closely related to the habitat and environmental conditions. Therefore, it can explain the form of distinction of the existing population. Generally, individuals with an incomplete membrane arrangement and widened disks live in the litter area or on the trees. This is consistent with the statements of Iskandar (1998) and Kusrini (2013) that Philautus aurifasciatus has a habitat close to shrubs and trees. However, some were also found not far from water bodies but on tree leaves or branches. The genus Philautus does have a unique breeding strategy in the form of direct egg growth. The eggs are laid on the ground or in the gaps within the tree trunks and the tadpoles grow inside the eggs. After the development process is complete, small frogs will hatch through the egg membrane (Iskandar, 1998). Based on these characteristics, Philautus should belong to the tree frog family.
The results of the overall character analysis did not showed a very dominant meristic character that can be used as a diagnosis for each population of Philautus from Mount Ungaran and Gede Pangrango. The morphological characteristics of Philautus from Mount Ungaran pointed to that of Philautus aurifasciatus from Mount Gede Pangrango because their meristic character are similar. After the comparison, there was no difference between the two mountain locations based on meristic analysis with similar characteristics. However, there are new findings that Philautus spp. found in Mount Ungaran has morphological variations consisting of four types of dorsal patterns, namely $\mathrm{H}, \mathrm{X}, \mathrm{V}$, and abstract, and has three types of snouts including protruding, round, and sloping.

\section{The determining factor for the similarity of Philautus spp. from Mount Ungaran with Philautus aurifasciatus from Mount Gede Pangrango}

Specimens of Philautus spp. from Mount Ungaran are thought to have originated from the same species as Philautus aurifasciatus on Mount Gede Pangrango. This is because Mount Ungaran and Gede Pangrango are located in a mountain range of Java. Some of taxonomic literature mentions that the several discovery of Philautus aurifasciatus was on 
the Java Island (Tschudi, 1838; Barbour, 1912;Dubois \& Ohler, 2001). This is also supported by the discovery of Philautus aurifasciatus in Java which was widely described and distributed in several mountains such as Mount Gede, Mount Pangrango, Mount Salak, Mount Halimun, Mount Ungaran, and Mount Merapi (Van Kampen, 1923; Iskandar, 1998; Frost, 2020). Philautus from Mount Ungaran and Gede Pangrango has a morphology that is difficult to distinguish, supported by similarities of its meristic character. Even though they are in different mountain locations, the species have similar habitat types and do not go through an extreme adaptation process that require extreme morphological changes. Furthermore, species separation can occur due to various kinds of isolation, such as in the case of Philautus mjobergi and Philautus nephophilus, Philautus nephophilus is described as a new species separated from Philautus mjobergi even though it is distributed in the island of Borneo due to differences in habitat and altitude. Morphologically, the two are similar, but the bioacoustic sound of calls are very different with a genetic distance of $4.8 \%$ based on the phylogeny analysis (Dehling et al. 2016). Moreover, evaluation on the taxonomic status of Sumatran Philautus using molecular analyses resulted on the finding of four new species (Wostl et al., 2017). The overall data showed that there was no morphological variation as indicated by the absence of a significant dominant diagnostic character which distinguishes each population from Mount Ungaran and Mount Gede Pangrango. Meanwhile, species separation cannot be ascertained because Philautus aurifasciatus has a fairly small environmental tolerance range. Based on the results of the analysis in the discussion, it is concluded that Philautus spp. from Mount Ungaran is a similar species compared to Philautus aurifasciatus from Mount Gede Pangrango in terms of meristic characters.

The description of the meristic analysis result can be provide scientific information on the Philautus of Mount Ungaran, in particulary can be used as a basis for strengthening the taxonomic status Philautus of Mount Ungaran. Besides, the results of this analysis can also be used to provide the distribution information of Philautus on Mount Ungaran. Further study using molecular and acoustic data are needed to confirm the result of this study.

\section{CONCLUSION}

Philautus spp. from Mount Ungaran is a similar species compared to Philautus aurifasciatus from Gunung Gede Pangrango with characteristic variations in dorsal body color; 4 types of patterns (letters of $\mathrm{H}, \mathrm{X}$, and $\mathrm{V}$, and abstract patterns); granular throat, abdomen, and lower thighs; 3 types of snout (protruding, round, and sloping); clear tympanum and canthus rostralis; sloped loreal; fold of skin over the tympanum; non-webbed fingers of the forelimbs and half webbed toes of the hindlimbs; oval-shaped inner metatarsals.

\section{ACKNOWLEDGEMENTS}

The authors are grateful to the Research Center for Biology, Indonesian Institute of Sciences (LIPI), Cibinong. We thank Mulyadi, Wahyu Trilaksono, and Syaripudin for the assistance during specimen examination in Museum Zoologicum Bogoriense. We thank the Ministry of Education and Culture for the funding, and also to Mr. Partaya as the supervisors that provided directions and suggestions. Finally, thanks are also given to Perum Perhutani for giving the permission in Mount Ungaran area, as well as for Green Community and people that have provided support in this study.

\section{REFERENCES}

Barbour, T. (1908). Some new Amphibia Salientia. Proceedings of the Biological Society of Washington, 21: 189-190.

Barbour, T. (1912). A contribution to the zoogeography of the East Indian Islands. Memoirs of the Museum of Comparative Zoology. Memoirs of the Museum of Comparative Zoology at Harvard College., 44 (1): 1 - 203

Bossuyt, F., \& A. Dubois. (2001). A Review of the frog genus Philautus Gistel, 1848 (Amphibia, Anura, Ranidae, Rhacoporinae). Zeylonica, 6: 1112

Biju, S.D., Garg, S., Gokulakrishnan, G., Chandrakasan, S., Thammachoti, P., Ren, J., Gopika, C., Bisht, K., Hamidy, A., Shouche, Y. (2020). New insights on the systematics and reproductive behaviour in tree frogs of the genus Feihyla, with description of a new related genus from Asia (Anura, Rhacophoridae). Zootaxa, 4878 (1): 001-055.

Dehling, J.M., M. Matsui, \& P.Y. Imbun. (2016). A new small montane species of Philautus (Amphibia: Anura: Rhacoporidae) from Mount Kinabalu, Sabah, Malaysia (Borneo). Salamandra, 52: 77-90.

Dring, J.(1987). Bornean tree frogs of the genus Philautus. Amphibia-Reptilia, 8: 19-47.

Dubois, A., \& Ohler, A. (2001). Systematics of the genus Philautus Gistel, 1848 (Amphibia, Anura, Ranidae, Rhacophorinae): some historical and metataxonomic comments. Journal of South Asian National History., 5 (2): 109-122 
Frost, Darrel R. (2020). Amphibian Species of the World: an Online Reference. Version 6.1 (10 Maret 2020). Electronic Database accessible at https://amphibiansoftheworld.amnh.org/index.php. American Museum of Natural History. New York, USA. DOI: $10.5531 / \mathrm{db} . v z .0001$

Inger R.F. (2005). The Systematic and Zoogeography of The Amphibian of Borneo. Borneo: Natural History Publications.

Iskandar, D. T. (1998). Amfibi Jawa dan Bali. Bogor: Puslitbang Biologi-LIPI.

Kuhl, H., \& Van Hasselt, J. C. (1822). Uittreksels uit brieven van de Heeren Kuhl en Van Hasselt, aan de Heeren C. J. Temminck, Th. Van Swinderen en W. De Haan. Algemeene Konst- en. (Extract Report on Kuhl Dan van Hasselt's trip) LetterBode, 7: 99-104

Kusrini, M.D. (2013). Panduan Bergambar Identifikasi Amfibi Jawa Barat. Bogor: Fakultas Kehutanan IPB.

Kusrini, M.D., M.I. Lubis, B. Darmawan \& L. Nuraini. (2017). Morphological and Ecological Observations on Chiromantis vittiger (Anura: Rhacophoridae) in Mount Halimun - Salak National Park, Indonesia. Treubia, 44: 47-66.

Malkmus, R., U. Manthey, G. Vogel, P. Hoffmann, \& J. Kosuch. (2002). Amphibians and Reptiles of Mount Kinabalu (north Borneo). Germany: A.R.G. Gantner Verlag KG.

Matsui, M. (2009). A new species of Philautus (Amphibian, Anura, Racoporidae) from the lowland of Sarawak, Western Borneo. Zoological Science, 26: 437-442.

Rahayuningsih, M., N.E. Kartijono, \& A. Retnoningsih. (2017a). Short Communication:
The nest characteristics of Wreathed Hornbill (Rhyticeros undulatus) in Mount Ungaran, Central Java, Indonesia. Biodiversitas, 18(3): 1130-1134.

Rahayuningsih, M., N.E. Kartijono, A. Retnoningsih. M. Munir, J. Dhalan. (2017b) The nest record of Wreathed Hornbill (Rhyticeros undulatus) in Gunung Gentong Station, Mount Ungaran Central Java. J. Phys: Conf. Ser. 824012061

Qurniawan, T.F. (2014). Observasi Variasi Corak dan Warna Philautus aurifasciatus (Schlegel, 1837) di Populasi Taman Nasional Gunung Merapi Yogyakarta. Fauna Tropika, 23(2): 68-74.

Schlegel, H. (1837). Abbildungen neuer oder unvollständig bekannter Amphibien (Images of new or incompletely known Amphibians). [First part.] Düsseldorf, Arnz \& Comp.: 1-31, pl. 1-10.

Tschudi, J. J. (1838). Classification der Batrachier, mit Berücksichtigung der fossilen Thiere dieser Abtheilung der Reptilien. Neuchâtel, Petitpierre: i-ii + 1-98, pl. 1-6.

Van Kampen, P.N. (1912). Notes from the Leyden Museum. In Javanische Amphibien gesammelt vom Edw. Jacobson. Netherlands: EJ. Brill Ltd. Leiden.

Van Kampen, P.N. (1923). The Amphibian of the Indo-Australian Archipelago. Netherlands: EJ. Brill Ltd. Leiden..

Wostl, E., A. Riyanto, A. Hamidy, N. Kurniawan, N.S. Eric, \& B.H. Harvey. (2017). A Taxonomic Revision of the Philautus (Anura: Rhacophoridae) of Sumatra with the Description of Four New Species. Zootaxa, 4072: 477-495. 